\title{
Persistent and extreme outliers in causes of death by state, 1999-2013
}

Francis P Boscoe

In the United States, state-specific mortality rates that are high relative to national rates can result from legitimate reasons or from variability in coding practices. This paper identifies instances of state-specific mortality rates that were at least twice the national rate in each of three consecutive five-year periods (termed persistent outliers), along with rates that were at least five times the national rate in at least one five-year period (termed extreme outliers). The resulting set of 71 outliers, 12 of which appeared on both lists, illuminates mortality variations within the country, including some that are amenable to improvement either because they represent preventable causes of death or highlight weaknesses in coding techniques. Because the approach used here is based on relative rather than absolute mortality, it is not dominated by the most common causes of death such as heart disease and cancer. 
1

2

3

Persistent and extreme outliers in causes of death by state, 1999-2013

4

Francis P. Boscoe, New York State Cancer Registry

5

6

7

8

9 New York State Cancer Registry

10150 Broadway, Suite 361

11 Albany, NY 12204 USA

12 francis.boscoe@health.ny.gov

13 


\section{Abstract}

18 In the United States, state-specific mortality rates that are high relative to national rates can result

19 from legitimate reasons or from variability in coding practices. This paper identifies instances of

20 state-specific mortality rates that were at least twice the national rate in each of three consecutive

21 five-year periods (termed persistent outliers), along with rates that were at least five times the

22 national rate in at least one five-year period (termed extreme outliers). The resulting set of 71

23 outliers, 12 of which appeared on both lists, illuminates mortality variations within the country,

24 including some that are amenable to improvement either because they represent preventable

25 causes of death or highlight weaknesses in coding practices. Because the approach used here is

26 based on relative rather than absolute mortality, it is not dominated by the most common causes

27 of death such as heart disease and cancer. 


\section{Introduction}

This paper builds upon the findings of the paper, "The Most Distinctive Causes of Death by State, 2001-2010”, published in the online journal Preventing Chronic Disease in May, 2015 (Boscoe and Pradhan, 2015). That paper - formally a "GIS Snapshot", consisting of a single map and accompanying short description - presented the most distinctive cause of death for each state and the District of Columbia for the 2001-2010 period. "Most distinctive" was defined as the highest ratio of state-specific death rate to national death rate for each of the causes of death included in the 113 Selected Causes of Death List published by the National Center for Health Statistics (2002). For example, the age-adjusted death rate due to pneumoconiosis nationwide was 0.3 per 100,000, but in Kentucky, it was 1.0 and in West Virginia it was 3.9. The respective ratios of 3.3 and 12.4 were higher than for any other cause of death in these states, making them the most distinctive. The mapped causes of death can also be understood as those with the highest state-specific relative risks, the highest location quotients (Mayer and Pleeter, 1975), or as the largest outliers. In general, the identification of outliers is useful for assessing the integrity of a data set and to identify genuinely unusual phenomena that can give rise to hypotheses (Osborne and Overbay, 2004).

In the time since the original paper was first submitted for publication, three additional years of data have become available. I incorporate these data into an alternative way of conducting the analysis that identifies what I term persistent outliers and extreme outliers. Persistent outliers were those causes of death with an age-adjusted rate that was at least twice the national rate in each of the five-year time periods 1999-2003, 2004-2008, and 2009-2013.

Extreme outliers were defined as those causes of death with an age-adjusted rate that was at least 5 times above the national rate in at least one of the time periods. Identifying all of the outliers in 
53 this manner instead of identifying exactly one per state, as was done on the original map, is a

54 more inclusive means of summarizing the data.

\section{Methods}

National and state-specific age-adjusted death rates for all of the causes of death included in the 113 Selected Causes of Death List for the period 1999-2013 were obtained from Centers for Disease Control and Prevention (CDC) Wide-ranging Online Data for Epidemiologic Research (WONDER) web site (CDC, no date). This list was developed for the general analysis of mortality data and for ranking causes of death and is based on International Classification of Diseases version 10 (ICD-10) codes. The list includes some overlapping cause of death categories; including these results in a total of 136 causes of death. Data were divided into three 5-year periods: 1999-2003, 2004-2008, and 2009-2013. The ratios of the state rates to the national rates for each cause of death in each period were calculated, and persistent and extreme which includedcauses of death so rare that no data was reported for any state (as with measles, 12 deaths nationally in 15 years) or only reported for a few of the largest states (as with whooping cough, with data only reported for California and Texas). State-level counts between 11 and 19, marked by WONDER as "unreliable", were included in the analysis. 95\% confidence intervals around the ratios were determined using the RELRISK option in the FREQ procedure in SAS version 9.3 (SAS Institute, Cary NC). Results were tabulated for all causes of death in the list, even where the classifications overlapped, as for example with homicide, homicide by firearm, and homicide by other and unspecified means. An exception was made for "other and 
unspecified events of undetermined intent and their sequelae" and "events of undetermined intent", because these two categories were nearly identical - the first comprised over $99 \%$ of the second. Only the second, more inclusive category is reported here.

\section{Results}

There were 62 persistent outliers among 28 states plus the District of Columbia (Table 1). The District of Columbia had the most persistent outliers, with 9, while there were 22 states without any. There were 38 extreme outliers among 14 states plus the District of Columbia (Table 2). The District of Columbia led with 7, while 36 states did not have any. Twelve of the persistent outliers also appeared on the list of extreme outliers: water and air accidents (Alaska), events of undetermined intent (Maryland and Utah), other acute ischemic heart disease (Oklahoma and Virginia), influenza (South Dakota), and pneumoconiosis (West Virginia), plus five in the District of Columbia - HIV, homicide, homicide by firearm, hypertensive heart disease, and atherosclerotic cardiovascular disease. Table 2 also reveals that the number of extreme outliers has decreased over time. Between 1999 and 2003, there were 17; from 20042008 there were 13; and from 2009-2013 there were 8.

\section{Discussion}

The tables highlight instances where state mortality rates exceeded national rates by substantial margins. These can be understood as either genuine phenomena - where the risk of 
97 death due to a certain cause was truly elevated - or as artifacts of state-specific coding practices.

98 The former category includes unambiguous infectious and chronic diseases such as viral hepatitis

99 and pneumoconiosis, and well-specified types of accidents such as accidental drowning and

100 exposure to smoke, fire and flames. The latter category includes causes of death containing the

101 words “other", "unspecified” and "unknown", where a state, for whatever reason, was unable to

102 code deaths to the same level of specificity as other states.

103

There are a number of possible explanations for this lack of specificity. The information

104 could have truly been absent -a physician or coroner might have only indicated something like

"cardiac arrest" on the death certificate, for example, and there were insufficient resources to

follow up and obtain something more precise. It is also possible that coding guidelines may have

been interpreted overly strictly or literally, or may have been perceived as unclear, outcomes that are influenced by the experience level of the death certifier (Johnson et al., 2012). There could have also been instances of "motivated misreporting", in which the person filling out the death certificate may have had an incentive to be vague (Osborne and Overbay, 2004). An example of this has occurred in Maryland, where the state's chief medical examiner is on record that many "events of undetermined intent" - which include unresolved homicides, suicides, and accidents cannot be coded more specifically without input from the legal system, even though the medical determination of intent is distinct from the legal determination (Fenton, 2012). Critics have argued that this practice substantially suppresses the official homicide rate. Indeed, Maryland's rate of "events of undetermined intent" was 6 to 7 times above the national average in each of the

\section{3 time periods.}

For some of the reported outliers, it is not obvious whether the findings were genuine, an

119 artifact, or some combination of the two. For example, influenza, which appeared as an outlier in 
1209 different states (Iowa, Maine, Minnesota, Montana, Nebraska, North Dakota, South Dakota,

121 Vermont, and Wyoming), would seem to be a clearly defined cause of death. Yet the number of

122 deaths due to influenza is small, totaling 3,697 in 2013 (CDC, 2015). Influenza deaths are

123 perceived as common because people tend to be more familiar with the counts of influenza and

124 pneumonia combined (56,979 in 2013, placing it among the top ten causes of death nationwide

125 when so grouped), or the number of influenza-associated deaths (estimated at 20,000 to 30,000

126 annually, a number derived from mathematical models rather than death certificates) (Doshi,

127 2008; Thompson et al., 2009; CDC, 2015). Of the comparatively small number of deaths

128 officially ascribed to influenza, a minority were confirmed with a lab test (these receive ICD-10

129 codes J09 and J10), while the remainder were based on observation (these receive code J11). The

130 nine states with unusually high influenza death rates may simply have been more aggressive in

131 ordering lab tests, or more willing to have called influenza-like illness influenza, than to have

132 had a true excess risk.

133 Note that this analysis was only able to identify likely examples of substantial

134 overreporting in certain causes of death. There have also been well-documented examples of

135 substantial underreporting, such as with suicide (Klugman, Condran and Wray, 2013),

136 pregnancy-related deaths (Deneux-Tharaux et al., 2005), and injuries from falls (Betz, Kelly and

137 Fisher, 2008). In some cases, such as with “events of undetermined intent”, the overreported

138 category can imply which categories were likely underreported, but a separate analysis would be

139 required to identify properly these negative outliers; such an analysis would be complicated by

140 the suppression of counts less than 10. For the present analysis, the suppression of counts less

141 than 10 might have masked some potentially interesting information (for example, if the 12 
142 measles deaths had been concentrated in just a few states), but by definition would not have

143 included anything of widespread public health importance.

144 Each one of the causes of death highlighted in the tables suggests a story about mortality

145 disparities, mortality coding disparities, or some combination of the two that demands further

146 investigation. In the interest of brevity, I will comment only on the dozen entries which appeared

147 in both tables. The District of Columbia, with 5 of the 12, revealed itself as an outlier among

148 outliers. Though not a state, its data are typically reported with the 50 states, as was done here. It

149 is unique among "states" in having an African-American majority and being entirely urban. It

150 also has the highest poverty rate and income inequality of any "state", making it an outlier by

151 numerous measures. The high rates of HIV-related deaths and homicide seen here reflect the

152 urban pathologies of intravenous drug use and crime, while hypertensive heart disease and

153 atherosclerotic cardiovascular disease reflect DC's racial composition, even while the precise

154 reasons for greater hypertension among black Americans remain elusive (Fuchs, 2011).

155 Moving to Alaska, the classification "water, air and space, and other and unspecified

156 transport accidents and their sequelae" has a straightforward explanation: travel by water and air

157 is vastly more common here than in other states, and is the only way to reach many settlements

158 within the state. Pneumoconioses, more commonly known as black lung disease, has a similarly

159 obvious association with West Virginia, the state most closely associated with coal mining.

160 "Events of undetermined intent", with high rates in Maryland and Utah, has already been

161 discussed, as has influenza, with particularly high rates in South Dakota.

162 That leaves "other acute ischemic heart disease", which appeared in both Oklahoma and

163 Virginia. From 1995 to 1999, the rate for this cause of death was over 25 times the national

164 average in Oklahoma, making it the most extreme outlier in this entire analysis. The rate 
165 subsequently dropped to 9 times the national average in 2008-2013, still one of the more extreme

166 values. This is a clear example of coding imprecision, reflecting an inability to distinguish

167 among chronic heart disease, heart attack (myocardial infarction), and a few other less common

168 conditions in a manner not shared by other states. For any studies which distinguish among types

169 of ischemic heart disease (see, for example, Ibfelt, Bonde and Hanson, 2010), care would have to

170 be taken to make sure that the results were not biased by the data from these two states.

The need for uniform standards for cause of death coding, and for public health data

172

173

174

175

176

177

178

179

180

181

182

184

185

186

187

generally, is obvious - in order to compare conditions in different places and times, the

measurement of those conditions must be done in as similar a manner as possible. The drop in

the number of extreme outliers over time suggests that standardization has been improving.

Massachusetts and Rhode Island represent good examples of this trend. Both of these states had very high rates of "events of undetermined intent" in 1999-2003, but by 2009-2013 were below

the national average. Public health agencies are continuously trying to improve standards and data quality; for example, since 2012, the National Center for Health Statistics has been flagging rare causes of death such as those caused by vaccine preventable diseases and requesting that states follow up and attempt to verify them (CDC, 2014). Findings such as those reported here can also serve to motivate improvements, as no state wants to be identified as an outlier for a preventable cause of death or an indicator of low data quality.

Cause of death coding based on the International Classification of Diseases is the most widely used system in the world and enables comparisons between countries and across decades. While no such system can ever be perfect or tell us everything we would like to know, it is in our collective interest to strive for the highest data quality possible. 


\section{References}

Betz ME, Kelly SP, Fisher J. Death certificate inaccuracy and underreporting of injury in elderly

191 people. Journal of the American Geriatrics Society 2008; 56: 2267-2272.

Boscoe FP, Pradhan E. The most distinctive causes of death by state. Preventing Chronic Disease 2015, 12: 140395.

Centers for Disease Control and Prevention. 2014. Improvements to the National Vital Statistics System. On line: http://www.cdc.gov/nchs/data/factsheets/factsheet_nvss_improvements.htm. Accessed July 20, 2015.

Centers for Disease Control and Prevention. 2015. Detailed Tables for the National Vital Statistics Report (NVSR) “Deaths: Final Data for 2013”. On line: http://www.cdc.gov/nchs/data/nvsr/nvsr64/nvsr64_02.pdf. Accessed July 20, 2015.

Centers for Disease Control and Prevention. No date. About Underlying Cause of Death, 19992010. On line: http://wonder.cdc.gov/ucd-icd10.html. Accessed July 20, 2015. United States and Europe. Obstetrics \& Gynecology 2005; 106: 684-692. Public Health 2008; 98: 939-945. 
207 Fenton J. Raising doubt on homicide count: unusual ruling in city heroin overdoes throws

208 spotlight on many deaths of 'undetermined' cause. Baltimore Sun 2012; June 11, A1.

209 Fuchs FD. Why do black Americans have higher prevalence of hypertension? An enigma still

210 unsolved. Hypertension 2011; 57: 383-389.

211 Galea S, Tracy M, Hoggatt KJ, DiMaggio C, Karpati A. Estimated deaths attributable to social

212 factors in the United States. American Journal of Public Health 2011; 101: 1456-1465.

213 Ibfelt E, Bonde JP, Hansen J. Exposure to metal welding fume particles and risk for

214 cardiovascular disease in Denmark: a prospective cohort study. Occupational and Environmental

215 Medicine 2010; 67: 772-777.

216 Johnson CJ, Hahn CG, Fink AK, German RR. Variability in cancer death certificate accuracy by

217 characteristics of death certifiers. American Journal of Forensic Medicine and Pathology 2010;

$218 \quad 31: 232-235$.

219 Klugman J, Condran G, Wray M. The role of medicological systems in producing geographic

220 variation in suicide rates. Social Science Quarterly 2013; 94(2): 462-489.

221 Mayer W, Pleeter S. A theoretical justification for the use of location quotients. Regional Science 222 and Urban Economics 1975; 5: 343-355. 
223 National Center for Health Statistics. 2002. Instruction manual, part 9: ICD-10 cause-of-death

224 lists for tabulating mortality statistics. On line:

225 http://www.cdc.gov/nchs/data/dvs/im9 2002.pdf.pdf. Accessed July 20, 2015.

226 Osborne JW, Overbay A. The power of outliers (and why researchers should always check for

227 them). Practical Assessment, Research and Evaluation 2004; 9(6).

228 Thompson WW, Moore MR, Weintraub E, Cheng PY, Jin X, Bridges CB, Bresee JS, Shay DK.

229 Estimating influenza-associated deaths in the United States. American Journal of Public Health

$230 \quad 2009 ;$ 99: S225-S230. 


\section{Table 1 (on next page)}

Persistent outliers, by state, 1999-2013 
1 Table 1. Persistent outliers, by state, 1999-2013.

\begin{tabular}{|c|c|c|c|c|c|c|c|}
\hline & & \multicolumn{2}{|c|}{$1999-2003$} & \multicolumn{2}{|c|}{$2004-2008$} & \multicolumn{2}{|c|}{$2009-2013$} \\
\hline State & Cause of Death & Deaths & RR & Deaths & $\mathrm{RR}$ & Deaths & RR \\
\hline Alabama & $\begin{array}{l}\text { Symptoms, signs and } \\
\text { abnormal clinical and } \\
\text { laboratory findings, not } \\
\text { elsewhere classified (R00- } \\
\text { R99) }\end{array}$ & 5550 & $\begin{array}{c}2.31 \\
(2.25-2.37)\end{array}$ & 6829 & $\begin{array}{c}2.69 \\
(2.63-2.76)\end{array}$ & 7882 & $\begin{array}{c}2.88 \\
(2.81-2.94)\end{array}$ \\
\hline Alabama & $\begin{array}{l}\text { Accidental discharge of } \\
\text { firearms (W32-W34) }\end{array}$ & 209 & $\begin{array}{c}3.81 \\
(3.31-4.38)\end{array}$ & 161 & $\begin{array}{c}3.27 \\
(2.79-3.83)\end{array}$ & 127 & $\begin{array}{c}2.47 \\
(2.07-2.95)\end{array}$ \\
\hline Alabama & $\begin{array}{l}\text { Other heart diseases (I26- } \\
\text { I51) }\end{array}$ & 28255 & $\begin{array}{c}2.11 \\
(2.09-2.14)\end{array}$ & 30196 & $\begin{array}{c}2.28 \\
(2.26-2.31)\end{array}$ & 30702 & $\begin{array}{c}2.12 \\
(2.10-2.14)\end{array}$ \\
\hline Alabama & Heart failure (I50) & 10894 & $\begin{array}{c}2.44 \\
(2.39-2.48)\end{array}$ & 10225 & $\begin{array}{c}2.31 \\
(2.27-2.36)\end{array}$ & 9981 & $\begin{array}{c}2.05 \\
(2.01-2.09)\end{array}$ \\
\hline Alaska & $\begin{array}{l}\text { Water, air and space, and } \\
\text { other and unspecified } \\
\text { transport accidents and their } \\
\text { sequelae (V90-V99, Y85) }\end{array}$ & 186 & $\begin{array}{c}9.19 \\
(7.95-10.63)\end{array}$ & 124 & $\begin{array}{c}6.09 \\
(5.10-7.27)\end{array}$ & 129 & $\begin{array}{c}6.09 \\
(5.12-7.25)\end{array}$ \\
\hline Alaska & Tuberculosis (A16-A19) & 13 & $\begin{array}{c}2.81 \\
(1.63-4.85)\end{array}$ & 13 & $\begin{array}{c}4.17 \\
(2.42-7.19)\end{array}$ & 18 & $\begin{array}{c}3.70 \\
(2.33-5.88)\end{array}$ \\
\hline Alaska & $\begin{array}{l}\text { Accidental drowning and } \\
\text { submersion (W65-W74) }\end{array}$ & 119 & $\begin{array}{c}3.11 \\
(2.60-3.73)\end{array}$ & 134 & $\begin{array}{c}3.44 \\
(2.90-4.08)\end{array}$ & 118 & $\begin{array}{c}2.95 \\
(2.46-3.54)\end{array}$ \\
\hline Alaska & $\begin{array}{l}\text { Intentional self-harm } \\
\text { (suicide) by discharge of } \\
\text { firearms (X72-X74) }\end{array}$ & 387 & $\begin{array}{c}2.16 \\
(1.96-2.39)\end{array}$ & 470 & $\begin{array}{c}2.53 \\
(2.31-2.77)\end{array}$ & 503 & $\begin{array}{c}2.49 \\
(2.28-2.72)\end{array}$ \\
\hline Alaska & $\begin{array}{l}\text { Other and unspecified } \\
\text { nontransport accidents and } \\
\text { their sequelae (W20-W31, } \\
\text { W35-W64, W75-W99, X10- } \\
\text { X39, X50-X59, Y86) }\end{array}$ & 301 & $\begin{array}{c}2.18 \\
(1.95-2.44)\end{array}$ & 292 & $\begin{array}{c}2.04 \\
(1.82-2.29)\end{array}$ & 320 & $\begin{array}{c}2.07 \\
(1.86-2.31)\end{array}$ \\
\hline Arizona & $\begin{array}{l}\text { Discharge of firearms, } \\
\text { undetermined intent (Y22- } \\
\text { Y24) }\end{array}$ & 62 & $\begin{array}{c}2.52 \\
(1.95-3.25)\end{array}$ & 80 & $\begin{array}{c}3.02 \\
(2.41-3.79)\end{array}$ & 63 & $\begin{array}{c}2.24 \\
(1.74-2.88)\end{array}$ \\
\hline
\end{tabular}




\begin{tabular}{|c|c|c|c|c|c|c|c|}
\hline Arkansas & $\begin{array}{l}\text { Discharge of firearms, } \\
\text { undetermined intent (Y22- } \\
\text { Y24) }\end{array}$ & 37 & $\begin{array}{c}3.10 \\
(2.24-4.30)\end{array}$ & 40 & $\begin{array}{c}3.46 \\
(2.53-4.74)\end{array}$ & 27 & $\begin{array}{c}2.04 \\
(1.40-2.99)\end{array}$ \\
\hline $\begin{array}{l}\text { District of } \\
\text { Columbia }\end{array}$ & $\begin{array}{l}\text { Hypertensive heart and renal } \\
\text { disease (I13) }\end{array}$ & 144 & $\begin{array}{c}4.82 \\
(4.09-5.68)\end{array}$ & 140 & $\begin{array}{c}5.16 \\
(4.37-6.09)\end{array}$ & 131 & $\begin{array}{c}4.47 \\
(3.76-5.31)\end{array}$ \\
\hline $\begin{array}{l}\text { District of } \\
\text { Columbia }\end{array}$ & $\begin{array}{l}\text { Human immunodeficiency } \\
\text { virus (HIV) disease (B20- } \\
\text { B24) }\end{array}$ & 1221 & $\begin{array}{c}8.49 \\
(8.02-8.99)\end{array}$ & 1015 & $\begin{array}{c}8.97 \\
(8.43-9.55)\end{array}$ & 536 & $\begin{array}{c}4.41 \\
(4.05-4.81)\end{array}$ \\
\hline $\begin{array}{l}\text { District of } \\
\text { Columbia }\end{array}$ & $\begin{array}{l}\text { Atherosclerotic } \\
\text { cardiovascular disease, so } \\
\text { described (I25.0) }\end{array}$ & 2794 & $\begin{array}{c}4.06 \\
(3.91-4.21)\end{array}$ & 2797 & $\begin{array}{c}5.06 \\
(4.88-5.25)\end{array}$ & 2338 & $\begin{array}{c}3.96 \\
(3.80-4.13)\end{array}$ \\
\hline $\begin{array}{l}\text { District of } \\
\text { Columbia }\end{array}$ & $\begin{array}{l}\text { Hypertensive heart disease } \\
\text { (I11) }\end{array}$ & 1375 & $\begin{array}{c}5.44 \\
(5.16-5.73)\end{array}$ & 936 & $\begin{array}{c}3.38 \\
(3.17-3.60)\end{array}$ & 852 & $\begin{array}{c}2.87 \\
(2.69-3.07)\end{array}$ \\
\hline $\begin{array}{l}\text { District of } \\
\text { Columbia }\end{array}$ & $\begin{array}{l}\text { Assault (homicide) by } \\
\text { discharge of firearms } \\
\text { (U01.4, X93-X95) }\end{array}$ & 756 & $\begin{array}{c}5.92 \\
(5.51-6.36)\end{array}$ & 650 & $\begin{array}{c}4.75 \\
(4.39-5.13)\end{array}$ & 381 & $\begin{array}{c}2.50 \\
(2.26-2.77)\end{array}$ \\
\hline $\begin{array}{l}\text { District of } \\
\text { Columbia }\end{array}$ & $\begin{array}{l}\text { Assault (homicide) U01- } \\
\text { U02, X85-Y09, Y87.1) }\end{array}$ & 990 & $\begin{array}{c}5.01 \\
(4.71-5.34)\end{array}$ & 827 & $\begin{array}{c}4.24 \\
(3.96-4.54)\end{array}$ & 535 & $\begin{array}{c}2.49 \\
(2.29-2.72)\end{array}$ \\
\hline $\begin{array}{l}\text { District of } \\
\text { Columbia }\end{array}$ & $\begin{array}{l}\text { Assault (homicide) by other } \\
\text { and unspecified means and } \\
\text { their sequelae (U01.0-U01.3, } \\
\text { U01.5-U01.9, U02, X85- } \\
\text { X92, X96-Y09, Y87.1) }\end{array}$ & 234 & $\begin{array}{c}3.49 \\
(3.07-3.97)\end{array}$ & 177 & $\begin{array}{c}3.16 \\
(2.72-3.66)\end{array}$ & 154 & $\begin{array}{c}2.48 \\
(2.12-2.91)\end{array}$ \\
\hline $\begin{array}{l}\text { District of } \\
\text { Columbia }\end{array}$ & Viral hepatitis (B15-B19) & 111 & $\begin{array}{c}2.09 \\
(1.74-2.52)\end{array}$ & 157 & $\begin{array}{c}2.63 \\
(2.24-3.07)\end{array}$ & 168 & $\begin{array}{c}2.47 \\
(2.12-2.87)\end{array}$ \\
\hline $\begin{array}{l}\text { District of } \\
\text { Columbia }\end{array}$ & $\begin{array}{l}\text { Pregnancy, childbirth and } \\
\text { the puerperium (O00-O99) }\end{array}$ & 10 & $\begin{array}{c}2.52 \\
(1.35-4.69)\end{array}$ & 28 & $\begin{array}{c}3.65 \\
(2.51-5.29)\end{array}$ & 21 & $\begin{array}{c}2.37 \\
(1.54-3.63)\end{array}$ \\
\hline Hawaii & $\begin{array}{l}\text { Accidental drowning and } \\
\text { submersion (W65-W74) }\end{array}$ & 153 & $\begin{array}{c}2.06 \\
(1.75-2.41)\end{array}$ & 169 & $\begin{array}{c}2.18 \\
(1.87-2.54)\end{array}$ & 227 & $\begin{array}{c}2.77 \\
(2.43-3.16)\end{array}$ \\
\hline Idaho & $\begin{array}{l}\text { Water, air and space, and } \\
\text { other and unspecified } \\
\text { transport accidents and their } \\
\text { sequelae (V90-V99, Y85) }\end{array}$ & 99 & $\begin{array}{c}2.35 \\
(1.93-2.86)\end{array}$ & 113 & $\begin{array}{c}2.63 \\
(2.19-3.17)\end{array}$ & 115 & $\begin{array}{c}2.41 \\
(2.01-2.90)\end{array}$ \\
\hline Iowa & Influenza (J09-J11) & 196 & 2.46 & 178 & 2.39 & 190 & 2.59 \\
\hline
\end{tabular}




\begin{tabular}{|c|c|c|c|c|c|c|c|}
\hline & & & $(2.13-2.83)$ & & $(2.06-2.78)$ & & $(2.24-2.99)$ \\
\hline Kansas & Atherosclerosis (I70) & 1706 & $\begin{array}{c}2.16 \\
(2.06-2.27)\end{array}$ & 1700 & $\begin{array}{c}3.32 \\
(3.16-3.48)\end{array}$ & 1941 & $\begin{array}{c}3.56 \\
(3.40-3.73)\end{array}$ \\
\hline Kentucky & $\begin{array}{l}\text { Pneumoconioses and } \\
\text { chemical effects (J60-J66, } \\
\text { J68) }\end{array}$ & 240 & $\begin{array}{c}3.01 \\
(2.65-3.43)\end{array}$ & 216 & $\begin{array}{c}3.27 \\
(2.86-3.75)\end{array}$ & 211 & $\begin{array}{c}2.88 \\
(2.51-3.31)\end{array}$ \\
\hline Louisiana & $\begin{array}{l}\text { Accidental discharge of } \\
\text { firearms (W32-W34) }\end{array}$ & 179 & $\begin{array}{c}3.15 \\
(2.72-3.66)\end{array}$ & 195 & $\begin{array}{c}3.99 \\
(3.45-4.61)\end{array}$ & 169 & $\begin{array}{c}3.41 \\
(2.92-3.98)\end{array}$ \\
\hline Louisiana & $\begin{array}{l}\text { Assault (homicide) by } \\
\text { discharge of firearms } \\
\text { (U01.4, X93-X95) }\end{array}$ & 2109 & $\begin{array}{c}2.35 \\
(2.25-2.45)\end{array}$ & 2298 & $\begin{array}{c}2.47 \\
(2.37-2.58)\end{array}$ & 2186 & $\begin{array}{c}2.34 \\
(2.24-2.44)\end{array}$ \\
\hline Louisiana & $\begin{array}{l}\text { Meningococcal infection } \\
\text { (A39) }\end{array}$ & 27 & $\begin{array}{c}2.91 \\
(1.99-4.27)\end{array}$ & 21 & $\begin{array}{c}3.51 \\
(2.27-5.43)\end{array}$ & 10 & $\begin{array}{c}2.05 \\
(1.10-3.83)\end{array}$ \\
\hline Louisiana & $\begin{array}{l}\text { Assault (homicide) (U01- } \\
\text { U02, X85-Y09, Y87.1) }\end{array}$ & 2834 & $\begin{array}{c}2.00 \\
(1.93-2.08)\end{array}$ & 2916 & $\begin{array}{c}2.14 \\
(2.07-2.22)\end{array}$ & 2765 & $\begin{array}{c}2.03 \\
(1.95-2.10)\end{array}$ \\
\hline Maine & Influenza (J09-J11) & 67 & $\begin{array}{c}2.15 \\
(1.69-2.73)\end{array}$ & 105 & $\begin{array}{c}3.50 \\
(2.89-4.25)\end{array}$ & 90 & $\begin{array}{c}2.72 \\
(2.21-3.35)\end{array}$ \\
\hline Maryland & $\begin{array}{l}\text { Events of undetermined } \\
\text { intent (Y10-Y34, Y87.2, } \\
\text { Y89.9) }\end{array}$ & 3144 & $\begin{array}{c}7.37 \\
(7.10-7.65)\end{array}$ & 3405 & $\begin{array}{c}6.99 \\
(6.74-7.24)\end{array}$ & 2990 & $\begin{array}{c}5.88 \\
(5.66-6.11)\end{array}$ \\
\hline Minnesota & Influenza (J09-J11) & 293 & $\begin{array}{c}2.57 \\
(2.28-2.89)\end{array}$ & 281 & $\begin{array}{c}2.62 \\
(2.33-2.95)\end{array}$ & 272 & $\begin{array}{c}2.41 \\
(2.14-2.73)\end{array}$ \\
\hline Mississippi & $\begin{array}{l}\text { Discharge of firearms, } \\
\text { undetermined intent (Y22- } \\
\text { Y24) }\end{array}$ & 37 & $\begin{array}{c}2.77 \\
(2.00-3.84)\end{array}$ & 34 & $\begin{array}{c}2.53 \\
(1.80-3.55)\end{array}$ & 34 & $\begin{array}{c}2.73 \\
(1.94-3.84)\end{array}$ \\
\hline Mississippi & $\begin{array}{l}\text { Hypertensive heart and renal } \\
\text { disease (I13) }\end{array}$ & 317 & $\begin{array}{c}2.18 \\
(1.95-2.43)\end{array}$ & 324 & $\begin{array}{c}2.37 \\
(2.12-2.64)\end{array}$ & 378 & $\begin{array}{c}2.55 \\
(2.31-2.83)\end{array}$ \\
\hline Mississippi & $\begin{array}{l}\text { Accidental discharge of } \\
\text { firearms (W32-W34) }\end{array}$ & 133 & $\begin{array}{c}3.75 \\
(3.15-4.45)\end{array}$ & 108 & $\begin{array}{c}3.30 \\
(2.72-4.00)\end{array}$ & 83 & $\begin{array}{c}2.53 \\
(2.03-3.14)\end{array}$ \\
\hline Mississippi & $\begin{array}{l}\text { Accidental exposure to } \\
\text { smoke, fire and flames }\end{array}$ & 452 & $\begin{array}{c}2.80 \\
(2.55-3.07)\end{array}$ & 398 & $\begin{array}{c}2.66 \\
(2.41-2.94)\end{array}$ & 377 & $\begin{array}{c}2.39 \\
(2.16-2.65)\end{array}$ \\
\hline
\end{tabular}




\begin{tabular}{|c|c|c|c|c|c|c|c|}
\hline & (X00-X09) & & & & & & \\
\hline Mississippi & $\begin{array}{l}\text { Hypertensive heart disease } \\
\text { (I11) }\end{array}$ & 2624 & $\begin{array}{c}2.16 \\
(2.08-2.25)\end{array}$ & 3416 & $\begin{array}{c}2.46 \\
(2.38-2.55)\end{array}$ & 3349 & $\begin{array}{c}2.24 \\
(2.17-2.32)\end{array}$ \\
\hline Mississippi & Heart failure (I50) & 6566 & $\begin{array}{c}2.42 \\
(2.36-2.28)\end{array}$ & 6879 & $\begin{array}{c}2.62 \\
(2.56-2.68)\end{array}$ & 6339 & $\begin{array}{c}2.24 \\
(2.18-2.29)\end{array}$ \\
\hline Montana & Influenza (J09-J11) & 72 & $\begin{array}{c}3.47 \\
(2.75-4.38)\end{array}$ & 43 & $\begin{array}{c}2.08 \\
(1.54-2.80)\end{array}$ & 72 & $\begin{array}{c}3.21 \\
(2.54-4.05)\end{array}$ \\
\hline Montana & $\begin{array}{l}\text { Intentional self-harm } \\
\text { (suicide) by discharge of } \\
\text { firearms (X72-X74) }\end{array}$ & 571 & $\begin{array}{c}2.11 \\
(1.94-2.29)\end{array}$ & 594 & $\begin{array}{c}2.14 \\
(1.97-2.32)\end{array}$ & 729 & $\begin{array}{c}2.44 \\
(2.26-2.62)\end{array}$ \\
\hline Montana & $\begin{array}{l}\text { Water, air and space, and } \\
\text { other and unspecified } \\
\text { transport accidents and their } \\
\text { sequelae (V90-V99, Y85) }\end{array}$ & 64 & $\begin{array}{c}2.07 \\
(1.62-2.65)\end{array}$ & 79 & $\begin{array}{c}2.64 \\
(2.12-3.30)\end{array}$ & 76 & $\begin{array}{c}2.43 \\
(1.94-3.05)\end{array}$ \\
\hline Montana & $\begin{array}{l}\text { Accidental discharge of } \\
\text { firearms (W32-W34) }\end{array}$ & 25 & $\begin{array}{c}2.18 \\
(1.47-3.23)\end{array}$ & 22 & $\begin{array}{c}2.02 \\
(1.33-3.08)\end{array}$ & 24 & $\begin{array}{c}2.34 \\
(1.57-3.50)\end{array}$ \\
\hline Nebraska & Influenza (J09-J11) & 115 & $\begin{array}{c}2.72 \\
(2.26-3.27)\end{array}$ & 86 & $\begin{array}{c}2.10 \\
(1.70-2.60)\end{array}$ & 96 & $\begin{array}{c}2.31 \\
(1.89-2.83)\end{array}$ \\
\hline Nebraska & $\begin{array}{l}\text { Symptoms, signs and } \\
\text { abnormal clinical and } \\
\text { laboratory findings, not } \\
\text { elsewhere classified (R00- } \\
\text { R99) }\end{array}$ & 2391 & $\begin{array}{c}2.33 \\
(2.23-2.42)\end{array}$ & 2228 & $\begin{array}{c}2.05 \\
(1.97-2.14)\end{array}$ & 2398 & $\begin{array}{c}2.03 \\
(1.95-2.11)\end{array}$ \\
\hline Nevada & $\begin{array}{l}\text { Legal intervention (Y35, } \\
\text { Y89.0) }\end{array}$ & 35 & $\begin{array}{c}2.46 \\
(1.76-3.44)\end{array}$ & 42 & $\begin{array}{c}2.72 \\
(2.01-3.69)\end{array}$ & 38 & $\begin{array}{c}2.36 \\
(1.71-3.25)\end{array}$ \\
\hline $\begin{array}{l}\text { New } \\
\text { Mexico }\end{array}$ & $\begin{array}{l}\text { Legal intervention (Y35, } \\
\text { Y89.0) }\end{array}$ & 36 & $\begin{array}{c}2.99 \\
(2.15-4.15)\end{array}$ & 34 & $\begin{array}{c}2.84 \\
(2.02-3.98)\end{array}$ & 50 & $\begin{array}{c}4.33 \\
(3.27-5.73)\end{array}$ \\
\hline $\begin{array}{l}\text { New } \\
\text { Mexico }\end{array}$ & $\begin{array}{l}\text { Alcoholic liver disease } \\
(\mathrm{K} 70)\end{array}$ & 932 & $\begin{array}{c}2.41 \\
(2.26-2.57)\end{array}$ & 969 & $\begin{array}{c}2.24 \\
(2.10-2.39)\end{array}$ & 1275 & $\begin{array}{c}2.72 \\
(2.57-2.87)\end{array}$ \\
\hline $\begin{array}{l}\text { New } \\
\text { Mexico }\end{array}$ & $\begin{array}{l}\text { Accidental poisoning and } \\
\text { exposure to noxious }\end{array}$ & 1268 & 2.65 & 1823 & 2.16 & 2261 & 2.56 \\
\hline
\end{tabular}




\begin{tabular}{|c|c|c|c|c|c|c|c|}
\hline & substances $(\mathrm{X} 40-\mathrm{X} 49)$ & & $(2.51-2.80)$ & & $(2.06-2.26)$ & & $(2.45-2.67)$ \\
\hline $\begin{array}{l}\text { North } \\
\text { Dakota }\end{array}$ & Influenza (J09-J11) & 42 & $\begin{array}{c}2.37 \\
(1.75-3.21)\end{array}$ & 47 & $\begin{array}{c}2.95 \\
(2.21-3.93)\end{array}$ & 38 & $\begin{array}{c}2.34 \\
(1.70-3.22)\end{array}$ \\
\hline Oklahoma & $\begin{array}{l}\text { Other acute ischemic heart } \\
\text { diseases (I24) }\end{array}$ & 5324 & $\begin{array}{l}25.20 \\
(24.44- \\
25.99)\end{array}$ & 4130 & $\begin{array}{c}18.52 \\
(17.90- \\
19.15)\end{array}$ & 2156 & $\begin{array}{c}8.95 \\
(8.56-9.35)\end{array}$ \\
\hline Oregon & $\begin{array}{l}\text { Meningococcal infection } \\
\text { (A39) }\end{array}$ & 16 & $\begin{array}{c}2.37 \\
(1.45-3.88)\end{array}$ & 12 & $\begin{array}{c}3.12 \\
(1.76-5.52)\end{array}$ & 12 & $\begin{array}{c}2.80 \\
(1.58-4.96)\end{array}$ \\
\hline $\begin{array}{l}\text { South } \\
\text { Carolina }\end{array}$ & $\begin{array}{l}\text { Other acute ischemic heart } \\
\text { diseases (I24) }\end{array}$ & 796 & $\begin{array}{c}3.43 \\
(3.20-3.69)\end{array}$ & 998 & $\begin{array}{c}3.67 \\
(3.44-3.91)\end{array}$ & 1356 & $\begin{array}{c}4.37 \\
(4.13-4.62)\end{array}$ \\
\hline $\begin{array}{l}\text { South } \\
\text { Dakota }\end{array}$ & Influenza (J09-J11) & 102 & $\begin{array}{c}5.07 \\
(4.17-6.17)\end{array}$ & 78 & $\begin{array}{c}4.18 \\
(3.35-5.23)\end{array}$ & 91 & $\begin{array}{c}4.57 \\
(3.72-5.63)\end{array}$ \\
\hline Utah & $\begin{array}{l}\text { Events of undetermined } \\
\text { intent (Y10-Y34, Y87.2, } \\
\text { Y89.9) }\end{array}$ & 889 & $\begin{array}{c}5.65 \\
(5.28-6.04)\end{array}$ & 1472 & $\begin{array}{c}7.44 \\
(7.06-7.84)\end{array}$ & 875 & $\begin{array}{c}4.00 \\
(3.74-4.28)\end{array}$ \\
\hline Utah & $\begin{array}{l}\text { Symptoms, signs and } \\
\text { abnormal clinical and } \\
\text { laboratory findings, not } \\
\text { elsewhere classified (R00- } \\
\text { R99) }\end{array}$ & 2275 & $\begin{array}{c}2.60 \\
(2.49-2.71)\end{array}$ & 3645 & $\begin{array}{c}3.72 \\
(3.60-3.84)\end{array}$ & 3427 & $\begin{array}{c}2.97 \\
(2.87-3.07)\end{array}$ \\
\hline Vermont & $\begin{array}{l}\text { Hyperplasia of prostate } \\
\text { (N40) }\end{array}$ & 12 & $\begin{array}{c}2.78 \\
(1.57-4.90)\end{array}$ & 15 & $\begin{array}{c}2.94 \\
(1.77-4.89)\end{array}$ & 19 & $\begin{array}{c}3.24 \\
(2.06-5.08)\end{array}$ \\
\hline Vermont & Influenza (J09-J11) & 38 & $\begin{array}{c}2.80 \\
(2.03-3.85)\end{array}$ & 36 & $\begin{array}{c}2.86 \\
(2.06-3.97)\end{array}$ & 33 & $\begin{array}{c}2.28 \\
(1.62-3.21)\end{array}$ \\
\hline Virginia & $\begin{array}{l}\text { Other acute ischemic heart } \\
\text { diseases (I24) }\end{array}$ & 2419 & $\begin{array}{c}6.21 \\
(5.95-6.48)\end{array}$ & 2699 & $\begin{array}{c}6.14 \\
(5.89-6.39)\end{array}$ & 2592 & $\begin{array}{c}5.19 \\
(4.98-5.41)\end{array}$ \\
\hline Virginia & $\begin{array}{l}\text { Pneumoconioses and } \\
\text { chemical effects (J60-J66, } \\
\text { J68) }\end{array}$ & 332 & $\begin{array}{c}2.62 \\
(2.35-2.93)\end{array}$ & 271 & $\begin{array}{c}2.51 \\
(2.22-2.84)\end{array}$ & 286 & $\begin{array}{c}2.31 \\
(2.05-2.60)\end{array}$ \\
\hline $\begin{array}{l}\text { West } \\
\text { Virginia }\end{array}$ & $\begin{array}{l}\text { Pneumoconioses and } \\
\text { chemical effects (J60-J66, } \\
\text { J68) }\end{array}$ & 557 & $\begin{array}{c}12.90 \\
(11.82-\end{array}$ & 414 & $\begin{array}{c}12.08 \\
(10.93-\end{array}$ & 338 & $\begin{array}{c}9.36 \\
(8.38-10.45)\end{array}$ \\
\hline
\end{tabular}




\begin{tabular}{|l|l|r|c|r|c|c|c|}
\hline & & & $14.07)$ & & $13.35)$ & & \\
\hline Wyoming & Influenza (J09-J11) & 34 & 3.45 & 19 & 2.13 & 38 & 3.52 \\
& & 331 & 2.24 & 330 & 2.19 & 440 & 2.65 \\
\hline Wyoming & $\begin{array}{l}\text { Intentional self-harm } \\
\text { (suicide) by discharge of } \\
\text { firearms (X72-X74) }\end{array}$ & $(2.01-2.49)$ & $(1.36-3.34)$ & & $(2.42-2.91)$ \\
\hline
\end{tabular}


Table 2 (on next page)

Extreme outliers, by state, 1999-2013 
1 Table 2. Extreme outliers, by state, 1999-2013.

\begin{tabular}{|c|c|c|c|c|c|c|c|}
\hline \multirow{2}{*}{ State } & \multirow[b]{2}{*}{ Cause of Death } & \multicolumn{2}{|c|}{ 1999-2003 } & \multicolumn{2}{|c|}{$2004-2008$} & \multicolumn{2}{|c|}{$2009-2013$} \\
\hline & & Deaths & RR & Deaths & RR & Deaths & RR \\
\hline Alaska & $\begin{array}{l}\text { Water, air and space, and } \\
\text { other and unspecified } \\
\text { transport accidents and } \\
\text { their sequelae (V90-V99, } \\
\text { Y85) }\end{array}$ & 186 & $\begin{array}{c}9.19 \\
(7.95-10.63)\end{array}$ & 124 & $\begin{array}{c}6.09 \\
(5.10-7.27)\end{array}$ & 129 & $\begin{array}{c}6.09 \\
(5.12-7.25)\end{array}$ \\
\hline Alaska & $\begin{array}{l}\text { Discharge of firearms, } \\
\text { undetermined intent } \\
\text { (Y22-Y24) }\end{array}$ & 19 & $\begin{array}{c}6.68 \\
(4.25-10.51)\end{array}$ & $<10$ & & 27 & $\begin{array}{c}8.30 \\
(5.67-12.15)\end{array}$ \\
\hline $\begin{array}{l}\text { District of } \\
\text { Columbia }\end{array}$ & $\begin{array}{l}\text { Human } \\
\text { immunodeficiency virus } \\
\text { (HIV) disease (B20-B24) }\end{array}$ & 1221 & $\begin{array}{c}8.49 \\
(8.02-8.99)\end{array}$ & 1015 & $\begin{array}{c}8.97 \\
(8.43-9.55)\end{array}$ & 536 & $\begin{array}{c}4.41 \\
(4.05-4.80)\end{array}$ \\
\hline $\begin{array}{l}\text { District of } \\
\text { Columbia }\end{array}$ & $\begin{array}{l}\text { Assault (homicide) by } \\
\text { discharge of firearms } \\
\text { (U01.4, X93-X95) }\end{array}$ & 756 & $\begin{array}{c}5.92 \\
(5.51-6.36)\end{array}$ & 650 & $\begin{array}{c}4.24 \\
(3.96-4.54)\end{array}$ & 381 & $\begin{array}{c}2.50 \\
(2.26-2.77)\end{array}$ \\
\hline $\begin{array}{l}\text { District of } \\
\text { Columbia }\end{array}$ & $\begin{array}{l}\text { Assault (homicide) (U01- } \\
\text { U02, X85-Y09, Y87.1) }\end{array}$ & 990 & $\begin{array}{c}5.01 \\
(4.71-5.34)\end{array}$ & 827 & $\begin{array}{c}4.74 \\
(4.39-5.13)\end{array}$ & 535 & $\begin{array}{c}2.49 \\
(2.29-2.72)\end{array}$ \\
\hline $\begin{array}{l}\text { District of } \\
\text { Columbia }\end{array}$ & $\begin{array}{l}\text { Hypertensive heart } \\
\text { disease (I11) }\end{array}$ & 1375 & $\begin{array}{c}5.44 \\
(5.16-5.73)\end{array}$ & 140 & $\begin{array}{c}5.16 \\
(4.37-6.09)\end{array}$ & 852 & $\begin{array}{c}2.87 \\
(2.69-3.07)\end{array}$ \\
\hline $\begin{array}{l}\text { District of } \\
\text { Columbia }\end{array}$ & $\begin{array}{l}\text { Atherosclerotic } \\
\text { cardiovascular disease, so } \\
\text { described (I25.0) }\end{array}$ & 2794 & $\begin{array}{c}4.06 \\
(3.91-4.21)\end{array}$ & 2797 & $\begin{array}{c}5.06 \\
(4.88-5.25)\end{array}$ & 2338 & $\begin{array}{c}3.96 \\
(3.80-4.13)\end{array}$ \\
\hline Iowa & $\begin{array}{l}\text { Other and unspecified } \\
\text { acute lower respiratory } \\
\text { infections (J22, U04) }\end{array}$ & 17 & $\begin{array}{c}2.76 \\
(1.70-4.46)\end{array}$ & 16 & $\begin{array}{c}5.32 \\
(3.23-8.77)\end{array}$ & $<10$ & \\
\hline Kansas & $\begin{array}{l}\text { Other and unspecified } \\
\text { acute lower respiratory } \\
\text { infections (J22, U04) }\end{array}$ & 58 & $\begin{array}{c}10.87 \\
(8.30-14.23)\end{array}$ & 17 & $\begin{array}{c}6.09 \\
(3.74-9.89)\end{array}$ & $<10$ & \\
\hline Louisiana & Syphilis (A50-A53) & 13 & $\begin{array}{c}9.23 \\
(5.26-16.19)\end{array}$ & $<10$ & & 16 & $\begin{array}{c}9.29 \\
(5.58-15.45)\end{array}$ \\
\hline Maryland & $\begin{array}{l}\text { Events of undetermined } \\
\text { intent (Y10-Y34, Y87.2, } \\
\text { Y89.9) }\end{array}$ & 3144 & $\begin{array}{c}7.37 \\
(7.10-7.65)\end{array}$ & 3405 & $\begin{array}{c}6.99 \\
(6.74-7.24)\end{array}$ & 2990 & $\begin{array}{c}5.88 \\
(5.66-6.11)\end{array}$ \\
\hline
\end{tabular}




\begin{tabular}{|c|c|c|c|c|c|c|c|}
\hline Maryland & Syphilis (A50-A53) & $<10$ & & 10 & $\begin{array}{c}5.65 \\
(2.99-10.65)\end{array}$ & $<10$ & \\
\hline Massachusetts & $\begin{array}{l}\text { Events of undetermined } \\
\text { intent (Y10-Y34, Y87.2, } \\
\text { Y89.9) }\end{array}$ & 2762 & $\begin{array}{c}5.54 \\
(5.33-5.77)\end{array}$ & 950 & $\begin{array}{c}1.71 \\
(1.61-1.83)\end{array}$ & 429 & 0.75 \\
\hline Nebraska & $\begin{array}{l}\text { Other and unspecified } \\
\text { acute lower respiratory } \\
\text { infections (J22, U04) }\end{array}$ & 24 & $\begin{array}{c}6.72 \\
(4.47-10.11)\end{array}$ & 20 & $\begin{array}{c}9.92 \\
(6.33-15.54)\end{array}$ & $<10$ & \\
\hline Oklahoma & $\begin{array}{l}\text { Other acute ischemic } \\
\text { heart diseases (I24) }\end{array}$ & 5324 & $\begin{array}{r}25.20 \\
(24.44- \\
25.99)\end{array}$ & 4130 & $\begin{array}{r}18.52 \\
(17.90- \\
19.15)\end{array}$ & 2156 & $\begin{array}{c}8.95 \\
(8.56-9.35)\end{array}$ \\
\hline Rhode Island & $\begin{array}{l}\text { Events of undetermined } \\
\text { intent (Y10-Y34, Y87.2, } \\
\text { Y89.9) }\end{array}$ & 425 & $\begin{array}{c}5.24 \\
(4.76-5.77)\end{array}$ & 271 & $\begin{array}{c}3.01 \\
(2.67-3.40)\end{array}$ & 60 & 0.65 \\
\hline South Dakota & Influenza (J09-J11) & 102 & $\begin{array}{c}5.07 \\
(4.17-6.17)\end{array}$ & 78 & $\begin{array}{c}4.18 \\
(3.35-5.23)\end{array}$ & 91 & $\begin{array}{c}4.57 \\
(3.72-5.62)\end{array}$ \\
\hline Utah & $\begin{array}{l}\text { Events of undetermined } \\
\text { intent (Y10-Y34, Y87.2, } \\
\text { Y89.9) }\end{array}$ & 889 & $\begin{array}{c}5.65 \\
(5.28-6.04)\end{array}$ & 1472 & $\begin{array}{c}7.44 \\
(7.06-7.84)\end{array}$ & 875 & $\begin{array}{c}4.00 \\
(3.74-4.28)\end{array}$ \\
\hline Vermont & $\begin{array}{l}\text { Other nutritional } \\
\text { deficiencies (E50-E64) }\end{array}$ & 11 & $\begin{array}{c}4.77 \\
(2.63-8.63)\end{array}$ & $<10$ & & 27 & $\begin{array}{c}12.59 \\
(8.59-18.46)\end{array}$ \\
\hline Virginia & $\begin{array}{l}\text { Other acute ischemic } \\
\text { heart diseases (I24) }\end{array}$ & 2419 & $\begin{array}{c}6.21 \\
(5.95-6.48)\end{array}$ & 2699 & $\begin{array}{c}6.14 \\
(5.89-6.39)\end{array}$ & 2592 & $\begin{array}{c}5.19 \\
(4.98-5.41)\end{array}$ \\
\hline West Virginia & $\begin{array}{l}\text { Pneumoconioses and } \\
\text { chemical effects (J60-J66, } \\
\mathrm{J} 68 \text { ) }\end{array}$ & 557 & $\begin{array}{r}12.90 \\
(11.82- \\
14.07)\end{array}$ & 414 & $\begin{array}{r}12.08 \\
(10.93- \\
13.35)\end{array}$ & 338 & $\begin{array}{c}9.36 \\
(8.38-10.45)\end{array}$ \\
\hline
\end{tabular}

2 